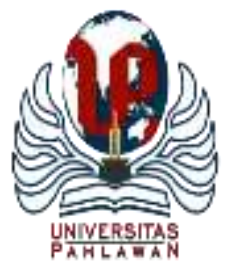

Edukatif : Jurnal Ilmu Pendidikan Volume 3 Nomor 6 Tahun 2021 Halm 3954 - 3961

EDUKATIF: JURNAL ILMU PENDIDIKAN

Research \& Learning in Education

https://edukatif.org/index.php/edukatif/index

\title{
Analisa Kebutuhan Karakter untuk Pengembangan Bahan Ajar Bahasa Inggris di Sekolah Dasar
}

\author{
Rindilla Antika $^{1 凶}$, Elsy Melia Syari $^{2}$ \\ STKIP Nasional, Padang Pariaman, Indonesia ${ }^{1,2}$ \\ E-mail : dillarindilla@gmail.com ${ }^{1}$, citrakhansacosmetic@ gmail.com ${ }^{2}$
}

\begin{abstract}
Abstrak
Penelitian ini dilatar belakangi oleh kebutuhan bahan ajar bahasa Inggris yang mengintegrasikan antara kebutuhan hardskills dan kebutuhan softskills. Penelitian ini bertujuan untuk menganalisis kebutuhan karakter apa saja yang perlu dikembangkan dalam bahan ajar bahasa Inggris untuk siswa kelas V SD. Penelitian ini merupakan deskriptif kualitatif dengan partisipan dalam penelitian ini adalah guru dan siswa kelas V di salah satu sekolah dasar swasta di Kota Pariaman. Instrumen dalam penelitian adalah angket dan pedoman wawancara. Hasil penelitian menunjukkan bahwa siswa memerlukan karakter percaya diri, bekerja keras, dan kreatif, sedangkan kebutuhan karakter yang perlu dikembangkan dari segi guru adalah karakter percaya diri, tanggung jawab, dan bekerja keras. Dengan demikian baik guru maupun siswa memerlukan sebuah bahan ajar yang dapat mendukung pendidikan karakter yang dapat menanamkan nilai seperti sikap percaya diri, tanggung jawab,kreatif, dan senang bekerja keras.
\end{abstract}

Kata Kunci: Analisa Kebutuhan, Bahan Ajar Pendidikan Karakter

\section{Abstract}

The background of this research was a need of integrated English teaching material both hard skills and soft skills. This research aimed to analyze character needs to be developed on English teaching material for fifthgrade of elementary school. This research was descriptive qualitative research which the participants were teachers and students of a private elementary school in Pariaman City. The data were collected through questionnaires and interviews. The results showed that the students need confident, hard work, and creative values whereas the teachers need to develop confident, responsible, and hard work values in learning English. Thus, both students and teachers need a learning material which can support character education and instill confident, responsible, creative, and hard work values.

Keywords: Need Analysis, Learning Material, Character Education

Copyright (c) 2021 Rindilla Antika, Elsy Melia Syari

$\triangle$ Corresponding author

Email : dillarindilla@gmail.com

DOI $\quad:$ https://doi.org/10.31004/edukatif.v3i6.1354

ISSN 2656-8063 (Media Cetak)

ISSN 2656-8071 (Media Online) 


\section{Analisa Kebutuhan Karakter untuk Pengembangan Bahan Ajar Bahasa Inggris di Sekolah Dasar- Rindilla Antika, Elsy Melia Syari \\ DOI: https://doi.org/10.31004/edukatif.v3i6.1354}

\section{PENDAHULUAN}

Pendidikan karakter sebaiknya dapat dilaksanakan pada semua jenjang pendidikan di sekolah namun di jenjang sekolah dasar pendidikan karakter harus lebih diutamakan. Hal ini disebabkan karena pembentukan karakter dimulai sedari dini, jika tidak dibentuk sejak dini, maka akan sulit untuk merubah karakter seseorang (Mahatma, 2010; Permono, 2013). Pendidikan karakter anak sebenarnya bukan hanya tanggung jawab sekolah melainkan orang tua di rumah yang juga memiliki peranan penting. Keluarga merupakan sekolah pertama bagi anak namun kenyataanya orang tua di rumah terlalu sibuk dengan pekerjaan dan urusan mereka masing-masing sehingga perkembangan pendidikan karakter anaknya kurang diperhatikan dan sebagian besar orang tua di rumah melimpahkan pendidikan karakter anaknya kepada pihak sekolah. Hal tersebut merupakan alasan mendasar sekolah sebagai sarana pendidikan formal dijadikan wadah pembentukan karakter anak sehingga di sekolah guru harus lebih intensif dalam membentuk karakter peserta didiknya agar anak-anak tersebut mampu membentuk Indonesia sebagai bangsa yang berkarakter di masa yang akan datang (Nuh, 2017).

Salah satu tujuan dari Pendidikan Nasional menurut UU No. 20 Tahun 2003 adalah menghasilkan peserta didik yang memiliki nilai moral yang baik yaitu menjadi seorang peserta didik yang berakhlak mulia, bermoral, bertanggung jawab, dan religius (Pawitasari et al., 2015) atau dapat dikatakan tujuan Pendidikan Nasional adalah menghasilkan siswa yang berkarakter. Pendidikan karakter merupakan upaya yang dilakukan dengan menciptakan situasi belajar yang dapat memenuhi pengembangan diri siswa dengan interaksi belajar yang dapat membangun dan membentuk karakter siswa (Islam, 2017). Karakter merupakan nilai perilaku manusia yang berhubungan dengan Tuhan YME, diri sendiri, sesama manusia, lingkungan, dan kebangsaan yang diwujudkan dalam pikiran, sikap, perkataan, perbuatan, dan menjadi dasar norma - norma yang ada pada masyarakat. Karakter seseorang merupakan suatu kebiasaan yang diperoleh dari keteladanan atau contoh dari lingkungan sekitar yang akan menjadi ciri perilaku orang tersebut (Sudrajat, 2011). Pembentukan dan pengembangan karakter dapat dilakukan di rumah dan di lingkungan sekitar melalui bimbingan orang tua dan masyarakat, tetapi peran sekolah dalam pembentukan karakter siswa juga penting (Suyadi, 2013). Siswa tentu akan memperhatikan tingkah laku orang-orang yang berada disekitarnya sehingga untuk membentuk karakter anak, orang tua dan guru yang merupakan orang-orang yang dekat dengan siswa harus memberikan contoh perilaku karakter kepada siswa. Pada intinya jika kita ingin mengembangkan karakter anak maka didiklah anak dengan sikap yang berkarakter pula.

Pendidikan karakter disebut juga sebagai pendidikan nilai, pendidikan budi pekerti, pendidikan moral, dan pendidikan watak yang bertujuan untuk membangun dan mengembangkan kemampuan peserta didik dalam memberikan keputusan baik - buruk, memelihara yang baik dan mewujudkan kebaikan dalam kehidupan sehari - hari dengan sepenuh hati. Pendidikan karakter merupakan pemahaman nilai agama, budaya, sosial, dan moral yang dapat membentuk akhlak dan kepribadian manusia menjadi lebih bermoral dan berbudi pekerti luhur sehingga dapat meneladani dan menilai sikap yang baik dalam kehidupan sehari hari (Wulandari \& Kristiawan, 2017). Pelaksanaan pendidikan karakter di sekolah membutuhkan pemahaman dari semua pihak yang berada di lingkungan dunia pendidikan sehingga pengajarannya dapat menumbuhkan budi pekerti luhur kepada peserta didik sesuai dengan tujuan yang diharapkan. Menurut Prasetyo \& Rivashinta (2015) pelaksanaan pendidikan karakter di sekolah harus melibatkan semua komponen pendidikan yaitu kurikulum, proses pembelajaran, evaluasi, pengelolaan mata pelajaran, pengelolaan sekolah, pelaksanaan aktivitas, pembiayaan, etos kerja warga dan lingkungan sekolah. Pendidikan karakter bukan hal baru dalam dunia pendidikan Indonesia karena pendidikan karakter telah diajarkan pada mata pelajaran Pendidikan Agama dan Pendidikan Kewarganegaraan (PKn). Pendidikan karakter merupakan suatu program pengembangan dunia pendidikan di Indonesia yang harus direalisasikan sehingga peran serta kita semua sangat dibutuhkan untuk mendukung program tersebut. 


\section{Analisa Kebutuhan Karakter untuk Pengembangan Bahan Ajar Bahasa Inggris di Sekolah Dasar- Rindilla Antika, Elsy Melia Syari \\ DOI: https://doi.org/10.31004/edukatif.v3i6.1354}

Pembentukan karakter dapat diwujudkan salah satunya dengan bahan ajar berbasis karakter. Bahan ajar mempunyai peranan yang penting dalam proses pembelajaran. Bahan ajar merupakan bentuk uraian dari isi kurikulum yang telah disusun dengan sangat jelas dengan penuh ilustrasi untuk mencapai tujuan dan hasil pembelajaran yang diinginkan yang disampaikan oleh penyelenggara pendidikan seperti guru atau tutor kepada peserta didik (Oktariyani \& Juwita, 2020; Sesmiyanti et al., 2018). Bahan ajar mempunyai peranan penting dan memiliki posisi sentral yaitu; 1) bahan ajar adalah representasi pendidik dalam kelas yang mana informasi dan penjelasan yang harus disampaikan di depan kelas telah disatukan dalam bahan ajar sehingga pendidik memiliki banyak waktu dalam membimbing siswa dalam proses pembelajaran. Peranan bahan ajar yang kedua adalah bahan ajar sebagai alat atau saran untuk mencapai kompetensi yang ingin dicapai dalam indikator pembelajaran. Selain itu, bahan ajar juga merupakan bentuk pelayanan satuan pendidikan yang mana bahan ajar disusun secara sistematis, rapi, dan bertahap sesuai dengan kebutuhan dan minat siswa yang disajikan dengan metode yang memotivasi, dan penunjang bagi latihan dan tugas praktis sebagai alat evaluasi (Bahtiar, 2015; Rizal, 2019).

Permasalahan yang dibahas pada penelitian ini adalah karakter apa yang dibutuhkan baik siswa maupun guru kelas lima di salah satu sekolah dasar swasta di kota Pariaman pada pembelajaran bahasa Inggris. Sebagaimana diketahui, bahasa Inggris di sekolah dasar merupakan mata pelajaran yang termasuk dalam kategori muatan lokal yaitu mata pelajaran yang diajarkan sesuai dengan kebutuhan sekolah tersebut (Gumiandari, 2021; Harmanto, 2015). Hal ini didasari karena belum adanya bahan ajar yang mengintegrasikan antara kebutuhan untuk peningkatan kemampuan dan kebutuhan untuk pengajaran pendidikan karakter khususnya dalam pengajaran bahasa Inggris di sekolah dasar kota Pariaman. Penelitian ini bertujuan untuk mengetahui kebutuhan pendidikan karakter pada muatan lokal bahasa Inggris di kelas lima sekolah dasar. Hasil analisa kebutuhan pendidikan karakter ini nantinya akan digunakan sebagai dasar pengembangan bahan ajar bahasa Inggris berorientasi pada pendidikan karakter. Dengan pengintegrasian pendidikan karakter pada bahan ajar bahasa Inggris diharapkan dapat menghasilkan peserta didik yang mempunyai kemampuan bahasa Inggris yang baik dan kecerdasan emosional yang bagus.

Penelitian yang relevan dengan penelitian ini adalah penelitian yang dilakukan oleh Suharto (2020) yang berjudul "Analisis Kebutuhan Siswa SD Terhadap Bahan Ajar Bahasa Inggris Berbasis Budaya Lokal Sunda". Hasil penelitian ini menunjukkan bahwa pelestarian budaya lokal dapat dilakukan dengan mengintegrasikannya dengan pembelajaran bahasa asing yaitu bahasa Inggris. Penelitian lain juga menunjukkan bahwa pengintegrasian pendidikan karakter kreatif dengan bahan ajar berbasis game based learning juga diperlukan dalam pembelajaran dengan tema ekosistem di kelas V SDN Bendogerit 2 Kota Blitar (Wati et al., 2020). Selain itu, penelitian yang dilakukan oleh Muktadir (2016) menunjukkan bahwa model bahan ajar muatan lokal berbasis cerita rakyat untuk pendidikan karakter siswa SD di Kota Bengkulu diperlukan sebagai sumber bahan ajar. Bahan ajar yang dihasilkan dilengkapi dengan ilustrasi dan latihan untuk meningkatkan kemampuan kognitif, afektif, dan psikomotor. Berdasarkan penelitian yang telah dilakukan ini, belum ada penelitian yang menggali tentang kebutuhan pendidikan karakter pada pembelajaran bahasa Inggris, maka dari itu peneliti tertarik untuk menggali, mengidentifikasi, dan mengembangkan pendidikan karakter dalam pelajaran muatan lokal bahasa Inggris.

\section{METODE PENELITIAN}

Penelitian ini dilakukan dengan menggunakan pendekatan kualitatif. Pendekatan kualitatif adalah suatu proses penelitian dan pemahaman yang berdasarkan pada metodologi yang menyelidiki suatu fenomena sosial dan masalah manusia. Pada pendekatan ini, peneliti membuat suatu gambaran kompleks, meneliti kata-kata, laporan terinci dari pandangan responden, dan melakukan studi pada situasi yang alami dengan pertimbangan 
3957 Analisa Kebutuhan Karakter untuk Pengembangan Bahan Ajar Bahasa Inggris di Sekolah DasarRindilla Antika, Elsy Melia Syari

DOI: https://doi.org/10.31004/edukatif.v3i6.1354

bahwa data yang akan diperoleh dari penelitian ini merupakan data deskriptif kualitatif (Ary et al., 2018; Sugiyono, 2015) .

Partisipan pada penelitian ini adalah guru dan murid kelas lima di salah satu sekolah dasar swasta di Kota Pariaman. Sekolah yang menjadi subjek dalam penelitian ini adalah sekolah dasar yang menerapkan pembelajaran bahasa Inggris. Guru yang menjadi responden adalah dua orang guru bahasa Inggris dan 50 orang siswa kelas lima yang mempelajari bahasa Inggris. Penelitian ini dilaksanakan selama satu bulan yaitu selama bulan Juni 2021. Dalam penelitian ini, peneliti bertindak sebagai instrumen dan pengumpul data di lapangan. Peneliti hanya sebagai seorang pengamat tanpa melaksanakan pengembangan pendidikan karakter di sekolah yang sehingga peneliti biasanya disebut sebagai pengamat penuh.

Teknik pengumpulan data pada penelitian ini dengan angket dan wawancara. Angket digunakan untuk mengetahui kebutuhan siswa terhadap pendidikan karakter dalam pembelajaran bahasa Inggris sedangkan wawancara diberikan kepada guru untuk mengidentifikasi kebutuhan karakter guru dan juga diberikan kepada siswa untuk memberikan tambahan informasi terhadap kebutuhan karakter yang diinginkan siswa. Sampel yang dipilih adalah heterogen dengan mempertimbangkan kondisi sosial dan budaya responden. Selain itu, responden yang dipilih oleh peneliti dianggap telah mewakili subyek atau informan dari penelitian ini. Data dianalisa dengan menggunakan reduksi data, penyajian data, dan penarikan kesimpulan dan verifikasi data (Sugiyono, 2015). Data dianalisa dengan melakukan triagulasi data yaitu dengan menggali kebenaran informasi tertentu dengan menggunakan berbagai macam sumber data yaitu wawancara dan angket. Data kualitatif ini harus berdasarkan kredibilitas dan triagulasi data yang berfungsi untuk mendapatkan kepercayaan hasil - hasil penemuan dengan jalan pembuktian oleh peneliti pada kenyataan ganda yang sedang diteliti (Maleong, 2010).

\section{HASIL DAN PEMBAHASAN PENELITIAN}

Hasil penelitian menunjukkan bahwa karakter yag dibutuhkan baik oleh siswa dan guru kelas lima di salah satu sekolah dasar swasta di Kota Pariaman pada mata pelajaran bahasa Inggris hampir sama. Hal tersebut dijabarkan dalam penjelasan berikut ini;

\section{Analisa Kebutuhan Karakter Siswa}

Analisa kebutuhan karakter siswa didapatkan dari penyebaran kuesioner dan wawancara kepada siswa. Kuesioner diberikan kepada 50 orang siswa sedangkan wawancara dilakukan pada tiga orang siswa sebagai perwakilan. Hasil angket siswa mengenai sikap atau karakter yang ingin dimiliki dalam pembelajaran bahasa Inggris menunjukkan bahwa sebanyak $48 \%$ siswa memilih ingin memiliki sikap percaya diri, sedangkan sebanyak 32\% siswa memilih untuk memiliki sikap senang bekerja keras, dan sebanyak 5\% siswa memilih sikap bertanggung jawab dan kreatif. Hal ini dapat dilihat pada tabel berikut ini;

\begin{tabular}{|c|c|c|}
\hline No. & Karakter & Persentase \\
\hline 1 & Percaya Diri & $48 \%$ \\
\hline 2 & Bekerja Keras & $32 \%$ \\
\hline 3 & Tanggung Jawab & $5 \%$ \\
\hline 4 & Kreatif & $5 \%$ \\
\hline
\end{tabular}

Hasil ini juga didukung dengan hasil wawancara siswa yang menunjukkan bahwa siswa ingin memiliki sikap percaya diri dalam pembelajaran bahasa Inggris karena mereka ingin percaya diri dalam berbicara atau berinteraksi dengan menggunakan bahasa Inggris. Hal ini sejalan dengan penelitian yang dilakukan oleh Muhsin \& Sastrawati (2014) yang menyatakan bahwa siswa memerlukan feedback untuk meningkatkan rasa 


\section{Analisa Kebutuhan Karakter untuk Pengembangan Bahan Ajar Bahasa Inggris di Sekolah Dasar- Rindilla Antika, Elsy Melia Syari \\ DOI: https://doi.org/10.31004/edukatif.v3i6.1354}

percaya diri karena dengan memiliki kepercayaan diri yang tinggi, siswa akan berani dalam memberikan tanggapan dan kritikan terhadap kondisi yang dihadapi serta berani untuk tampil di depan.

Hasil wawancara juga menunjukkan bahwa siswa memerlukan karakter bekerja keras dalam pembelajaran bahasa Inggris. Karakter ini diperlukan karena menurut pendapat siswa tersebut, kerja keras dibutuhkan dalam menyelesaikan tugas yang diberikan oleh guru terutama dalam pembelajaran bahasa Inggris. Hal ini disebabkan karena pembelajaran bahasa Inggris mempunyai tantangan tersendiri karena mereka belajar bahasa asing (Yamin, 2017) dan memerlukan pemahaman yang lebih dalam mengerjakan dan menyelesaikan tugas. Dalam pendidikan karakter yang terdapat dalam tujuan pendidikan nasional, kerja keras merupakan salah satu nilai karakter yang harus dimiliki oleh peserta didik (Aeni, 2014). Selain itu, hal ini juga sejalan dengan penelitian yang dilakukan oleh Agustini et al. (2014) yang menyatakan karakter kerja keras diperlukan dalam implementasi nilai karakter dalam pembelajaran bahasa Inggris karena karakter ini diperlukan dalam penyelesaian tugas dan latihan yang diberikan oleh guru.

Selain itu, hasil wawancara juga menunjukkan bahwa siswa membutuhkan nilai karakter tanggung jawab dan kreatif. Nilai karakter ini dibutuhkan karena siswa menginginkan sikap kreatif sehingga mereka dapat berkreasi dalam mempelajari dan mempraktikkan bahasa Inggris serta bertanggung jawab dalam mengerjakan tugas yang telah diberikan. Selain itu, siswa ingin memiliki sikap kreatif karena mereka ingin berbicara dengan menggunakan bahasa Inggris dalam pergaulan dan kehidupan sehari - hari. Pendidikan karakter selayaknya ditanamkan sejak dini karena sebagai seorang siswa penerus generasi bangsa, sikap dan perilakunya seyogyanya dapat mencerminkan orang terpelajar yang kaya akan pengetahuan dan keterampilan. Selain itu, pembelajaran sebaiknya juga dapat membentuk sikap kejujuran, tanggungjawab, toleransi, kepedulian, santun, percaya diri, dan cinta damai (Palunga \& Marzuki, 2017).

\section{Analisa Kebutuhan Karakter Guru}

Analisa kebutuhan karakter yang diinginkan dan dibutuhkan oleh guru dalam pembelajaran bahasa Inggris di kelas lima yang didapatkan berdasarkan hasil wawancara menunjukkan bahwa guru juga menginginkan dan membutuhkan karakter yang sama dengan siswa. Hasil analisa wawancara menunjukkan bahwa respon guru terhadap sikap yang harus dimiliki oleh siswa dalam pembelajaran bahasa Inggris yaitu sikap percaya diri, tanggung jawab, dan kreatif. Hal ini disebabkan karena dalam proses pembelajaran, siswa tampak masih ragu dengan kemampuan yang mereka miliki, siswa terlihat tidak percaya diri dengan apa yang telah mereka kerjakan dan usahakan. Selain itu, sikap tanggung jawab juga harus diajarkan dan diberikan kepada siswa karena siswa masih menunjukkan sikap kurang bertanggung jawab seperti masih ada siswa yang tidak mengerjakan tugas dan pekerjaan rumah. Sikap kreatif juga diharapkan dimiliki oleh siswa karena dengan sifat kreatif, siswa dapat mengembangkan kemampuannya dan tidak selalu mengandalkan guru dalam belajar.

Dalam pengintegrasian pendidikan karakter dalam pendidikan khususnya dalam proses pembelajaran, diperlukan kerjasama antara semua warga sekolah yang terlibat baik guru, kepala sekolah, tenaga kependidikan, masyarakat di lingkungan sekolah, dan orang tua (Suyadi, 2013). Tujuan pendidikan karakter di sekolah adalah untuk menjadikan peserta didik seorang yang unggul secara menyeluruh yaitu mempunyai pribadi yang cerdas intelektual, emosional, sosial, dan spiritual. Pendidikan karakter sebaiknya ditanamkan sejak jenjang pendidikan yang paling rendah yaitu Sekolah Dasar (SD) karena pada saat inilah karakter anak masih mudah dibentuk dan diperkenalkan serta ditanamkan dengan nilai positif sebagai bekal dalam menjalani kehidupan nantinya (Khilmiyah et al., 2015). Selain itu, dalam pengimplementasian pendidikan karakter diperlukan keterlibatan semua pihak baik sekolah maupun masyarakat untuk efektifitas pendidikan karakter. Sebagai tambahan, dengan pengintegrasian pendidikan karakter dalam kurikulum sebaiknya juga relevan dengan kehidupan peserta didik sehingga akan menantang mereka secara intelektual, emosional, dan sosial (Agboola \& Tsai, 2012). Dengan demikian, hasil analisa kebutuhan karakter ini, dapat dikembangkan 
3959 Analisa Kebutuhan Karakter untuk Pengembangan Bahan Ajar Bahasa Inggris di Sekolah DasarRindilla Antika, Elsy Melia Syari

DOI: https://doi.org/10.31004/edukatif.v3i6.1354

dan diintegrasikan dalam tema pembelajaran yang disesuaikan dengan kurikulum sekolah dasar sehingga peserta didik dapat mempelajari kecerdasan intelektual, sosial, emosional maupun spiritual.

Penelitian ini memiliki keterbatasan karena nilai pendidikan karakter yang diteliti terbatas hanya empat nilai karakter sedangkan nilai karakter berdasarkan Permendikbud No 20 (2018) terdapat delapan belas karakter yaitu religius, jujur, toleransi, disiplin, kerja keras, kreatif, mandiri, demokratis, rasa ingin tahu, semangat kebangsaan, cinta tanah air, menghargai prestasi, bersahabat/komunikatif, cinta damai, gemar membaca, peduli lingkungan, peduli sosial, dan tanggung jawab. Hasil penelitian ini diharapkan dapat menghasilkan sebuah bahan ajar yang dapat mengintegrasikan kebutuhan intelektual dan kebutuhan emosional, sosial, dan spiritual sehingga tujuan pendidikan nasioanal dapat tercapai.

\section{KESIMPULAN}

Berdasarkan hasil penelitian dapat disimpulkan bahwa sekolah dasar khususnya salah satu sekolah dasar swasta di kota Pariaman membutuhkan bahan ajar berbasis karakter dalam pembelajaran terutama pada subjek mata pelajaran bahasa Inggris. Hal tersebut dimaksudkan agar pendidikan karakter dapat berkembang dengan baik di sekolah. Karakter yang diharapkan adalah sikap percaya diri, tanggung jawab, dan senang bekerja keras. Karakter ini memang sangat diperlukan dalam pelajaran bahasa Inggris mengingat bahwa bahasa Inggris merupakan mata pelajaran bahasa asing bagi siswa sekolah dasar.

\section{UCAPAN TERIMA KASIH}

Peneliti ingin mengucapkan terima kasih kepada DPRM Kemenristekdikti atas pendanaan yang diberikan sehingga peneliti dapat menyelesaikan penelitian ini. Selain itu, peneliti juga mengucapkan terima kasih kepada pimpinan dan kolega di STKIP Nasional atas dukungan dan bantuannya dalam penyelesaian penelitian ini. Peneliti juga ingin mengucapkan banyak terima kasih kepada pimpinan dan guru di salah satu sekolah dasar swasta di Kota Pariaman yang telah mengizinkan peneliti untuk melakukan penelitian di sekolah tersebut.

\section{DAFTAR PUSTAKA}

Aeni, A. N. (2014). Pendidikan Karakter Untuk Siswa Sd Dalam Perspektif Islam. Mimbar Sekolah Dasar, 1(1), 50-58. Https://Doi.Org/10.17509/Mimbar-Sd.V1i1.863

Agboola, A., \& Tsai, K. C. (2012). Bring Character Education Into Classroom. European Journal Of Educational Research, 1(2), 163-170.

Agustini, D. A. E., Tantra, D. K., \& Wedhanti, N. K. (2014). Implementasi Nilai-Nilai Karakter Dalam Pembelajaran Bahasa Inggris. Jurnal Pendidikan Dan Pengajaran, 47(2-3), Article 2-3. Https://Doi.Org/10.23887/Jppundiksha.V47i2-3.4864

Ary, D., Jacobs, L. C., Irvine, C. K. S., \& Walker, D. (2018). Introduction To Research In Education. Cengage Learning.

Bahtiar, E. T. (2015). Penulisan Bahan Ajar. Https://Doi.Org/10.13140/Rg.2.1.1441.6083

Gumiandari, S. (2021). Introducing English To Early Childhood Through Singing With The Total Physical Response Method. Acitya: Journal Of Teaching And Education, 3(1), 86-94. Https://Doi.Org/10.30650/Ajte.V3i1.2138 
3960 Analisa Kebutuhan Karakter untuk Pengembangan Bahan Ajar Bahasa Inggris di Sekolah DasarRindilla Antika, Elsy Melia Syari

DOI: https://doi.org/10.31004/edukatif.v3i6.1354

Harmanto, B. (2015). Manajemen Pembelajaran Bahasa Inggris Di Sekolah Dasar/Madrasah Ibtidaiyah Kategori Unggul (Analysis Best Practice Pengajaran Bahasa Inggris Untuk Anak). Jurnal Dimensi Pendidikan Dan Pembelajaran, 3(1), 8.

Islam, S. (2017). Karakteristik Pendidikan Karakter; Menjawab Tantangan Multidimensional Melalui Implementasi Kurikulum 2013. Edureligia: Jurnal Pendidikan Agama Islam, 1(1), 89-100. Https://Doi.Org/10.33650/Edureligia.V1i2.50

Khilmiyah, A., Sumarno, S., \& Zuchdi, D. (2015). Pengembangan Model Penilaian Keterampilan Intrapribadi Dan Antarpribadi Dalam Pendidikan Karakter Di Sekolah Dasar. Jurnal Penelitian Dan Evaluasi Pendidikan, 19(1), 1-12. Https://Doi.Org/10.21831/Pep.V19i1.4550

Mahatma, Y. (2010, May 15). Mendiknas: Penerapan Pendidikan Karakter Dimulai Sd. Antara News. Https://Www.Antaranews.Com/Berita/186928/Mendiknas-Penerapan-Pendidikan-Karakter-Dimulai-Sd

Maleong, L. J. (2010). Metodologi Penelitian Kualitatif. Pt.Remaja Rosdakarya.

Muhsin, M. A., \& Sastrawati, I. (2014). Ketergabungan Pendidikan Karakter Dan Positive Feedback Dalam Pembelajaran Bahasa Inggris.

Muktadir, A. (2016). Pengembangan Model Bahan Ajar Mulok Berbasis Cerita Rakyat Untuk Pendidikan Karakter. Pgsd Jurnal Ilmiah Pendidikan Guru Sekolah Dasar, 8(3), 139-147.

Nuh, M. (2017, May 23). Pendidikan Karakter Dalam Membangun Kemandirian Bangsa [Website]. Fokus Kita. Https://Www.Uny.Ac.Id/Fokus-Kita/Prof-Dr-Ir-Kh-Mohammad-Nuh-Dea

Oktariyani, \& Juwita, R. P. (2020). Analisis Kebutuhan Bahan Ajar Bahasa Inggris Berbasis Local Learning Pada Siswa Sekolah Dasar. Jurnal Ilmu Pendidikan (Jip) Stkip Kusuma Negara Jakarta, 11(2), 95-101. Https://Doi.Org/10.37640/Jip.V11i2.93

Palunga, R., \& Marzuki, M. (2017). Peran Guru Dalam Pengembangan Karakter Peserta Didik Di Sekolah Menengah Pertama Negeri 2 Depok Sleman. Jurnal Pendidikan Karakter, 7(1), Article 1. Https://Doi.Org/10.21831/Jpk.V7i1.20858

Pawitasari, E., Mujahidin, E., \& Fattah, N. (2015). Pendidikan Karakter Bangsa Dalam Perspektif Islam (Studi Kritis Terhadap Konsep Pendidikan Karakter Kementerian Pendidikan \& Kebudayaan). Ta'dibuna: Jurnal Pendidikan Islam, 4(1), 1-20. Https://Doi.Org/10.32832/Tadibuna.V4i1.573

Permendikbud No 20. (2018). Peraturan Menteri Pendidikan Dan Kebudayaan Republik Indonesia Nomor 20 Tahun 2018 Tentang Penguatan Pendidikan Karakter Pada Satuan Pendidikan Formal. Https://Jdih.Kemdikbud.Go.Id/Arsip/Permendikbud_Tahun2018_Nomor20.Pdf

Permono, H. (2013). Peran Orangtua Dalam Optimalisasi Tumbuh Kembang Anak Untuk Membangun Karakter Anak Usia Dini. Http://Publikasiilmiah.Ums.Ac.Id/Handle/11617/3994

Prasetyo, A., \& Rivashinta, E. (2015, June 26). Konsep, Urgensi Dan Implementasi Pendidikan Karakter Di Sekolah.

Kompasiana.

Https://Www.Kompasiana.Com/Agusprasetyo/5500d253a33311537351205d/Konsep-Urgensi-DanImplementasi-Pendidikan-Karakter-Di-Sekolah

Rizal, S. (2019). Analisis Kebutuhan Bahan Ajar Bahasa Inggris Iain Bengkulu Melalui Students' Need Analysis. At-Ta'lim: Media Informasi Pendidikan Islam, 12(2), 232-252. Https://Doi.Org/10.29300/Attalim.V12i2.1632

Sesmiyanti, S., Antika, R., \& Yulmiati, Y. (2018). Persepsi Mahasiswa Tentang Pendidikan Karakter Pada Buku Teks Reading Di Perguruan Tinggi Swasta. Pena : Jurnal Pendidikan Bahasa Dan Sastra, 7(2), 119. Https://Doi.Org/10.22437/Pena.V7i2.5289

Sudrajat, A. (2011). Mengapa Pendidikan Karakter? Jurnal Pendidikan Karakter, 1(1), Article 1. Https://Doi.Org/10.21831/Jpk.V1i1.1316

Sugiyono, M. (2015). Penelitian \& Pengembangan (Research And Development/R\&D). Pnerbit Alfabeta. 
3961 Analisa Kebutuhan Karakter untuk Pengembangan Bahan Ajar Bahasa Inggris di Sekolah DasarRindilla Antika, Elsy Melia Syari

DOI: https://doi.org/10.31004/edukatif.v3i6.1354

Suharto, P. P. (2020). Analisis Kebutuhan Siswa Sd Terhadap Bahan Ajar Bahasa Inggris Berbasis Budaya Lokal Sunda. Metodik Didaktik: Jurnal Pendidikan Ke-Sd-An, 15(2), Article 2. Https://Doi.Org/10.17509/Md.V15i2.21679

Suyadi. (2013). Strategi Pembelajaran Pendidikan Karakter. Pt. Remaja Rosdakarya.

Wati, I. F., Yuniawatika, Y. Y., \& Murdiyah, S. (2020). Analisis Kebutuhan Terhadap Bahan Ajar Game Based Learning Terintegrasi Karakter Kreatif. Jurnal Pendidikan Karakter, 10(2), Article 2. Https://Doi.Org/10.21831/Jpk.V10i2.31880

Wulandari, Y., \& Kristiawan, M. (2017). Strategi Sekolah Dalam Penguatan Pendidikan Karakter Bagi Siswa Dengan Memaksimalkan Peran Orang Tua. Jmksp (Jurnal Manajemen, Kepemimpinan, Dan Supervisi Pendidikan), 2(2), 290-302. Https://Doi.Org/10.31851/Jmksp.V2i2.1477

Yamin, M. (2017). Metode Pembelajaran Bahasa Inggris Di Tingkat Dasar. 1(5), 16. 